\title{
MEASURING FOOD SECURITY IN THE REPUBLIC OF SERBIA ${ }^{12}$
}

\author{
Tatjana Papić Brankov ${ }^{3}$, Miloš Milovanovićc ${ }^{4}$
}

\begin{abstract}
Summary
The overall goal of this paper is analysis of Serbian food security system across a set of indicators, with special emphasis to 2012 Global Food Security Index (GFSI). The results generally provided two major weakness of the Serbian food system: Gross domestic product $(G D P)$ per capita based on purchasing power parity and Corruption. Paper points out the need to improve the current food security system and proposed a number of measures for its improvement. Among other things appropriate nutritional standards and strategies will have to be adopted; investors' confidence must be strengthened and must be dealt with in a serious fight against corruption in the agriculture and food sector. The development of rural areas, reducing regional disparities and stabilization of agricultural production will certainly contribute to the tough battle against poverty.
\end{abstract}

Key words: Food security, Poverty, GDP Purchasing power parity, Corruption

JEL: $Q 18,131, D 73$.

\section{Introduction}

The 2007 global food price crisis encouraged political and scientific interest in food security. In their July 2009 joint statement, the G8 heads of state agreed "to act with the scale and urgency needed to achieve sustainable global food security" (AFSI, 2009). Despite the fact that more than enough food is currently produced per capita to adequately feed the global population (Ingram, 2011), about 842 million people (12 percent of the global population) were unable to meet their dietary energy requirements in 2011-13 (FAO, 2013).

1 First version of this paper presented at 142nd Seminar of European Association of Agricultural Economists in Budapest, Hungary, May 29-30, 2014. Proceeding of the Seminar

2 Paper is a part of research within the project no. III 46006 - Sustainable agriculture and rural development in the function of accomplishing strategic objectives of the Republic of Serbia in the Danube region, financed by the Ministry of Education, Science and Technological Development of the Republic of Serbia. Project period: 2011-2015

3 Tatjana Papić Brankov, Research Associate, Institute of Agricultural Economics, Volgina Street no. 15, 11060 Belgrade, Serbia, Phone: +381 641021696 E-mail: brankov.tatjana@gmail.com

4 Miloš Milovanović, MsC, Policy Officer FAO, Internacionalnih brigada 69, 11000 Belgrade, Serbia, E-mail: milos.milovanovic@,fao.org

EP 2015 (62) 3 (801-812) 
For each of the physical, psychological and socio familial manifestations of food insecurity important social implications have been identified. Therefore, the key aspects of human development depend on food security (Hamelin et al., 1999). Even before the food and financial crises pushed hunger to unprecedented highs, malnutrition was the underlying cause of nearly 4.5 million child deaths every year (ActionAid, 2010). The loss of life caused by hunger is dwarfed by the invisible and permanent loss of human potential. Lack of food raises healthcare costs and reduces workforce productivity (Shepard et al., 2011; FAO, 2011; IMF, 2012). Food insecurity is correlated with a range of health-related outcomes: anemia (Eicher-Miller et al., 2009; Skaliky et al. 2006), aggression and anxiety (Whitaker et al., 2006) cognitive problems (Howard, 2011), lower nutrient intakes (Cook et al., 2004), dysthymia and other mental health issues (Alaimo et al., 2002), asthma (Kirkpatrick et al., 2007), behavioral problems (Huang et al., 2010), depression (Whitaker et al., 2006), diabetes (Seligman et al., 2007) etc.

Apart from this, food insecurity causes reduction of overall economic outputs and threatens political stability. Some estimates suggest that food insecurity costs developing economics around US\$450bn in lost GDP each year (ActionAid, 2010), what is more than 10 times the amount the UN estimates would be needed to achieve the Millennium Development Goals (MDGs) hunger targets. A food shortage is correlated with a significant deterioration of democratic institutions and a significant increase in the incidence of anti-government demonstrations, riots, and civil conflict in low-income countries (Arezki et al., 2010).

\section{The food security outcomes and their elements}

There are many definitions of food security. Commonly used definition from the 1996 World Food Summit (WFS) (FAO, 1996) states that food security exists when "all people, at all times, have physical and economic access to sufficient, safe, and nutritious food to meet their dietary needs and food preferences for an active and healthy life". Food security outcomes are grouped into three components: Availability, Accessibility and Utilization. Each component comprises three elements (Figure 1).

All nine elements have to be satisfied and stable over time for food security to be met. The stability of the three dimension over time is very important because adverse weather conditions, political instability, or economic factors (unemployment, rising food prices) may have an impact on the food security status. 
Figure 1. Food System outcomes

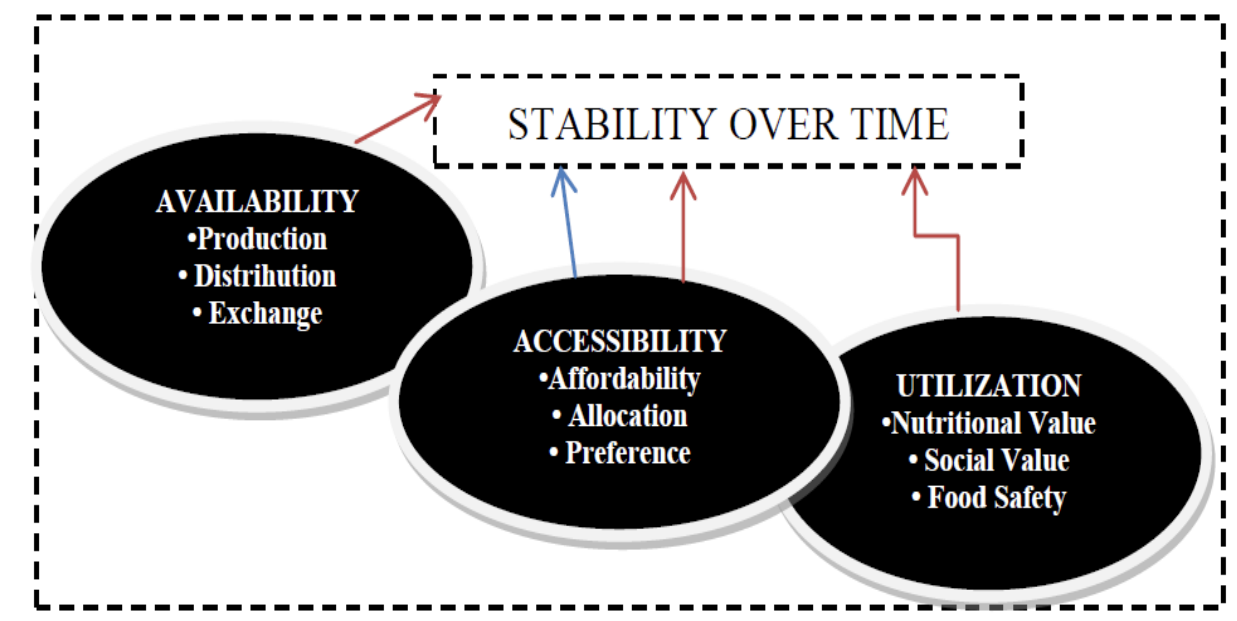

Source: Ingram (2011), modified by the authors.

Upon existing research of food security, in 2012, The Economist Intelligence Unit (EIU) has created Global Food Security Index (GFSI). Based on previously mentioned WFS definition EIU experts developed a modified definition of food security: "When people at all times have physical, social and economic access to sufficient and nutritious food that meets their dietary needs for a healthy and active life" (GFSI, 2012). They also modified internationally designed dimensions (FAO, 2006) of food security (Figure 1) and assessed food security across following three categories: Affordability and Financial Access, Availability, and Food Quality and Safety. These categories are further divided into a set of indicators that evaluate programmes, policies or practices that influence food security across a set of 107 countries. Affordability measures the ability of consumers to purchase food, their vulnerability to price shocks, and the presence of programmers and policies to support them when shocks occur. It is measured by six indicators: 1) Food consumption as a proportion of total household expenditure; 2) Proportion of population living under or close to the global poverty line; 3) GDP per capita (at purchasing power parity, exchange rates); 4) Agricultural import tariffs; 5) Presence of food safety net programmes; 6) Access to financing for farmers. Availability measures the sufficiency of the national food supply, the risk of supply disruption, national capacity to disseminate food, and research efforts to expand agricultural output. This category is measured across five indicators: 1) Sufficiency of supply; 2) Public expenditure on agricultural research and development (R\&D); 3) Agricultural infrastructure; 4) Volatility of agricultural production; 5) Political stability risk. Additionally, in 2013 two new indicators Corruption and Urban absorption capacity have been added to the availability category. Quality and safety measures what is sometimes called "utilization" in food security parlance. It assesses the variety and nutritional quality of average diets, as well as the safety of food. It is measured across five indicators: 1) Diet diversification; 2) Government commitment to increasing 
nutritional standards; 3) Micronutrient availability; 4) Protein quality; 5) Food safety. GFSI scores are calculated from the weighted mean of underlying indicators and scaled from 0 -100, where $100=$ most favorable.

\section{The situation in Serbia: Serbia GFSI overview}

Overall GFSI results based on relevant sources (FAO, WB, WTO, EIU, WHO) placed Serbia in the second out of four group of countries ${ }^{5}$. This was due to obtained general score of 56.8 in 2013 and somewhat slightly higher 59.6 score in 2012. By the number of points in the category of Affordability Serbia is ranked the place 44th out of 107 countries. In the same competition for parameters: Availability, and the Quality and Safety, Serbia ranks 51st and 41st, respectively. In the reporting period (2012-2013) Serbia has improved a parameter Quality and Safety (by 0.8), while two other parameters has regressed, Availability by 3.7 score and Affordability by 0.4 (Table 1).

Table 1. Serbia GFSI (July2012- July2013)

\begin{tabular}{|l|l|l|l|l|l|}
\hline Score/100 & 2012 & 2013 & Difference 2013 vs.2012 & Rank 2013/107 & $\begin{array}{l}\text { Difference } \\
\text { 2013 vs.2012 }\end{array}$ \\
\hline Overall & 59.6 & 56.8 & -2.8 & 49 & -3.0 \\
\hline Affordability & 62.1 & 61.7 & -0.4 & 44 & \\
\hline Availability & 55.1 & 51.4 & -3.7 & 51 & \\
\hline Quality and Safety & 65.5 & 66.3 & +0.8 & 41 & \\
\hline
\end{tabular}

Source: GFSI, 2012, 2013.

The EIU researcher analysed and gived differents scores for different elements of the Serbian food system as presented in Table 2. Three indicators: Proportion of population under global poverty line $(0.6 \%)$, Food safety and Diet diversification representing the strongest side of the system. On the other hand, the indicators which were evaluated worst are: Gross domestic product (GDP) per capita based on purchasing power parity, Corruption and Nutritional standards. Indicators with moderate score which should be improved are: Sufficienty of supply, Agricultural infrastructure, Urban absorption capacity, Protein quality, Public expenditure on agricultural R\&D, Micronutrient availability, Volatility of agricultural production, Political stability risk and Food consumption as a share of household expenditure.

\section{Weaknesses of food security system in Serbia}

As already mentioned, the biggest weakness of food security system in Serbia is GDP per capita PPP. As could be seen in Table 3 Serbian GDP purchasing power parity

5 Countries are grouped into quartiles so that the best scoring 25\% (top 27 countries, scores 70.1-87.3) are placed into a first group (,Best environment“"), the next $25 \%$ into the second group (scores 52.7-70.0), the next $25 \%$ are placed into the third group (scores 35.6-52.6) and the worst scoring $25 \%$ are placed into the fourth group. 
is significantly lower than in presented countries. The 2013 Serbian GDP purchasing power parity level was reached by Croatia in 2000, Hungary in 1999, Romania in 2007, Austria and EU in 1981 as well as major advanced economies (G7). In 2013 Austria and G7 have almost four times higher GDP per capita purchasing power parity than Serbia, while EU had the same indicator nearly three times higher than Serbia. Serbia is significantly falling behind even in comparisons to the newest member of EU- Croatia. Croatia in 2013 had a 1.6 times higher GDP purchasing power parity.Value of GDP purchasing power parity is in line with national poverty indicators. Dramatic decline in economic activity during the previous decade had an enormous impact on the increase in the number of the poor until 2000 (IMF, 2014). Research on poverty rates has shown that unemployment and inactivity are the basic causes of poverty and social exclusion in Serbia (Krstić, 2008).

Table 2. Analysis of the Serbian food system

\begin{tabular}{|c|c|c|}
\hline & & Score \\
\hline Strengths (score 75 or more) & $\begin{array}{l}\text { - Proportion of population under global poverty line } \\
\text { - Food safety } \\
\text { - Diet diversification } \\
\text { - Agricultural import tariffs } \\
\text { - Presence of food safety net programs } \\
\text { - Access to financing for farmers }\end{array}$ & $\begin{array}{l}\bullet 99.3 \\
\bullet 99.2 \\
\bullet 96.5 \\
\bullet 78.8 \\
\cdot 75.0 \\
\cdot 75.0 \\
\end{array}$ \\
\hline Moderate (score 25 to 75 ) & $\begin{array}{l}\text {-Sufficiency of supply } \\
\text { - Agricultural infrastructure } \\
\text { - Urban absorption capacity } \\
\text { - Protein quality } \\
\text { - Public expenditure on agricultural R\&D } \\
\text { - Micronutrient availability } \\
\text { - Volatility of agricultural production } \\
\text { - Political stability risk } \\
\text { - Food consumption as a share of household expenditure } \\
\text { - Nutritional standards } \\
\text { - Corruption }\end{array}$ & $\begin{array}{l}\cdot 67.4 \\
\cdot 61.1 \\
\cdot 56.5 \\
\cdot 55.0 \\
\cdot 50.0 \\
\cdot 47.6 \\
\cdot 40.5 \\
\cdot 38.9 \\
\cdot 36.2 \\
\cdot 34.6 \\
\cdot 25.0 \\
\end{array}$ \\
\hline Weaknesses (score less than 25) & -Gross domestic product per capita (PPP) & $\bullet 17.2$ \\
\hline
\end{tabular}

Source: GFSI, 2013

Table 3. GDP* purchasing power parity in Serbia and other countries (Int. \$), comparison

\begin{tabular}{|c|c|c|c|c|c|c|c|c|c|c|c|c|}
\hline & 1981 & 1985 & 1999 & 2000 & 2001 & 2002 & 2007 & 2009 & 2010 & 2011 & 2012 & 2013 \\
\hline Serbia & - & - & - & 5.7 & 6.1 & 6.5 & 9.7 & 10.0 & 10.3 & 10.7 & 10.7 & $\mathbf{1 1 . 1}$ \\
\hline Croatia & - & - & 10.1 & $\mathbf{1 1 . 2}$ & 11.7 & 12.4 & 17.8 & 17.4 & 17.3 & 17.7 & 17.6 & 17.7 \\
\hline Romania & - & - & 5.8 & 6.1 & 6.6 & 7.1 & $\mathbf{1 1 . 4}$ & 11.8 & 11.9 & 12.4 & 12.7 & 13.2 \\
\hline Hungary & - & - & $\mathbf{1 1 . 3}$ & 12.0 & 12.8 & 13.6 & 18.7 & 18.2 & 18.6 & 19.4 & 19.5 & 19.8 \\
\hline Austria & $\mathbf{1 1 . 3}$ & - & 27.3 & 28.8 & 29.6 & 30.4 & 38.5 & 38.3 & 39.3 & 41.0 & 41.9 & 42.5 \\
\hline EU & - & $\mathbf{1 1 . 2}$ & 20.6 & 21.9 & 22.8 & 23.4 & 30,0 & 29.3 & 30.2 & 31.2 & 31.6 & 31.9 \\
\hline G7 & $\mathbf{1 1 . 6}$ & 15.1 & 26.7 & 30.2 & 31.1 & 31.8 & 39.8 & 38.8 & 40.2 & 41.4 & 42.7 & 43.6 \\
\hline
\end{tabular}

*GDP based on purchasing power parity per capita is calculated in International Dollars and obtained from the World Economic Outlook Database 
Statistical data show that area differences in poverty are permanently present between rural and urban areas, and between different regions of Serbia ${ }^{6}$. In 2008, rural poverty decreased to $7.5 \%$ (compared to $11.2 \%$ in 2007), which was the lowest figure in the period 2002-2009. However, rural areas responded to the economic crisis and the percentage of the poor below the consumption-based absolute poverty line in rural areas increased from $7.5 \%$ to $9.6 \%$, which is twice as high as in urban areas (4.9\%). This trend continues in 2010, too. Regional disparities between Belgrade and Central Serbia are very huge. Percentage of the poor in Central Serbia (12\%) in 2010 was more than double higher than in Belgrade $(5.3 \%)$. The absolute poverty profile shows a strong correlation between poverty and the level of education. The most vulnerable groups are the least educated groups. Data in Table 4 is presented until 2010, because there is no official data available for the period after 2010. Only newspaper articles highlighted that the number of hungry children in 2013 is by 1.000 higher than in 2012 (Večernje novosti online, 2013).

Table 4. Absolute poverty line (CPI) ${ }^{7}$

\begin{tabular}{|l|c|c|c|c|c|}
\hline & 2006 & 2007 & 2008 & 2009 & 2010 \\
\hline Poverty line, RSD/month/consumer unit & 6.221 & 6.625 & 7.401 & 8.022 & 8.544 \\
\hline \% of the poor in RS & 8.8 & 8.3 & 6.1 & 6.9 & 9.2 \\
\hline$\%$ of the poor by region: & & & & & \\
\hline Belgrade & 4.3 & 2.4 & 2.9 & 3.8 & 5.3 \\
\hline Central Serbia & 10.7 & 9.0 & 7.0 & 9.3 & 12.0 \\
\hline Vojvodina & 8.6 & 11.9 & 6.8 & 4.9 & 6.8 \\
\hline$\%$ of the poor by type of settlement & & & & & \\
\hline Urban area & 5.3 & 6.0 & 5.0 & 4.9 & 5.7 \\
\hline Other area & 13.3 & 11.2 & 7.5 & 9.6 & 13.6 \\
\hline $\begin{array}{l}\text { \% of the poor by level of education of head } \\
\text { of household: }\end{array}$ & & & & & \\
\hline Incomplete primary school & 21.0 & 18.1 & 9.0 & 14.8 & 14.2 \\
\hline Primary school & 13.7 & 13.2 & 10.5 & 9.2 & 12.7 \\
\hline Secondary school & 5.5 & 5.4 & 4.8 & 3.0 & 4.8 \\
\hline College & 0.6 & 0.1 & 2.7 & 1.8 & 2.4 \\
\hline University & 1.8 & 0.4 & 1.9 & 0.6 & 0.8 \\
\hline
\end{tabular}

Source: Government of the Republic of Serbia, 2012 (http://www.inkluzija.gov.rs/wp-content/ uploads/2013/07/Monitoring-Social-Inclusion-in-Serbia-Aug-2012-ENG-revizija.pdf.

Question of malnutrition as an alternative poverty indicator (Setboonsarng, 2005) is very interesting in the case of Serbia. Analysis of Micronutrient availability indicator has shown that in contrast with vitamin A availability (100 score), availability of animal

6 The Republic of Serbia does not have a definition of rural areas based on standard indicators used internationally, so „other area“ is usually considered as rural areas.

7 Absolute poverty line defined on the basis of food line, raised for the amount of other expenditures (clothing, footwear, housing, health care, education, transport, sports, culture, other goods and services), computed in 2006 raised for the amount of inflation (Index of Consumer Prices) for each year. 
(30.6 score) and vegetal iron in $\mathrm{mg} /$ person/day is insufficient (12.1 score). According to FAO in 2001, prevalence of anemia among children under five was 18.8\%. Similarly, Institute for Public Health "Dr Milan Jovanovic Batut" pointed out that every third child in Serbia under the age of six is suffering from anemia (Večernje novosti online, 2013). This can be correlated with the increasing consumption of fast food as well as total absence of nutritional dietary guidelines and nutritional plan or strategy. Sufficiency of supply has been analyzed through dependency on chronic food aid and average food supply. Serbia is not dependent on food aid since 2004, when World Food Programme (WFP) ends operations in Serbia and Montenegro. FAO data indicate that dietary energy supply in 2011-13 in Serbia was $2.890 \mathrm{kcal} /$ capita/day (55.5 scores). If we take into consideration average adult needs of 2.300 calories per day to lead a healthy and active life, this means that Serbia is sufficiently supplied, but many less than developed countries. For example, dietary energy supply in the same period was $3.470 \mathrm{kcal} / \mathrm{capita} /$ day in Norway, $3.610 \mathrm{kcal} / \mathrm{capita} /$ day in Italy, and $3.650 \mathrm{kcal} / \mathrm{capita} /$ day in Greece. Supply is lower than in other Balkan countries $(3.180 \mathrm{kcal} / \mathrm{capita} /$ day in Croatia, Albania- $3.000 \mathrm{kcal} / \mathrm{capita} /$ day, Montenegro - $3.040 \mathrm{kcal} / \mathrm{capita} /$ day, Bosnia and Herzegovina- $3.030 \mathrm{kcal} /$ capita/day).

Second biggest weakness of the system is corruption with a moderate score of 25.0. Corruption interferes with a government's ability to develop and utilize effective agricultural policies and has a pernicious effect on food security, reducing available supply and raising costs. The destructive decisions against public benefit are taken (Aziz, 2001). This can lead to misuse of land and other resources (Papic Brankov et al., 2013). Three types of corruption, individual, business and political are observed in the agricultural sector of Serbia. For example, land registry officials are third most corrupt public officials, with nearly $6 \%$ of citizens who had interactions with them, resulting in a bribe being paid (UNODC, 2011). Transition in Serbia provided the opportunity for various forms of abuse and illegal behavior through the privatization of public ownership in the economy. Privatization of Serbian agribusiness was not being transparent, with frequent changes of legislation, in a kind of legal vacuum. During this process, in the past decade, more than 50.000 workers lost their jobs, which directly caused the increase of the hungry and poor. Thus, we can conclude that the level of corruption in Serbia is very high. After the democratic changes in 2000 Corruption Perceptions Index was 1.3, and in the meantime, this index increased almost three times to 3.5 , but the fight against corruption has not produce significant results still (Table 5). 
Table 5. Serbia Corruption perception index ${ }^{8}$

\begin{tabular}{|l|l|l|l|l|l|l|l|l|l|l|}
\hline & $\begin{array}{l}2000 \\
(\mathrm{Yu})\end{array}$ & $\begin{array}{l}2005 \\
(\mathrm{~S} \& \mathrm{M})\end{array}$ & 2006 & 2007 & 2008 & 2009 & 2010 & 2011 & 2012 & 2013 \\
\hline Score & 1.3 & 2.8 & 3.0 & 3.4 & 3.4 & 3.5 & 3.5 & 3.3 & 39 & 42 \\
\hline Rank & $89 / 90$ & $102 / 159$ & $90 / 163$ & $79 / 179$ & $85 / 180$ & $83 / 180$ & $78 / 178$ & $86 / 182$ & $80 / 176$ & $72 / 177$ \\
\hline
\end{tabular}

Source: www.transparency.org

Foreign investors, some of them personally affected by the global financial crisis, still hesitate to inject fresh capital into the Serbian market, waiting for better conditions, reflected in the harmonization of laws with EU standards, transparent operation of public services, easier and uniform administration procedures and most importantly, a stable political situation. Table 6 shows that Serbia is characterized by fluctuations in the volume of Foreign direct investment (FDI). The largest FDI net inflow is achieved in 2006 (4.153 million), after which there is a gradual reduction. Companies from the EU have been the leading investors in Serbia for the past eight years.

Table 6. Serbia: Foreign Direct Investments, in Cash (in 000 EUR)

\begin{tabular}{|l|l|l|l|l|l|l|l|l|l|}
\hline & 2005 & 2006 & 2007 & 2008 & 2009 & 2010 & 2011 & 2012 & 2013 \\
\hline Net & 1.162 .3 & 3.242 .6 & 1.448 .1 & 1.590 .0 & 1.305 .0 & 830.525 & 1.798 .5 & 220.4 & 755.9 \\
\hline Inflow & 1.215 .4 & $\mathbf{4 . 1 5 3 . 0}$ & 2.458 .5 & 2.193 .0 & 1.743 .0 & 1.107 .6 & 2.206 .8 & 2.126 .2 & 1.021 .3 \\
\hline $\begin{array}{l}\text { \% of EU FDI } \\
\text { from Total } \\
\text { FDI }\end{array}$ & 89.67 & 62.92 & 84.63 & 81.33 & 67.2 & 78.63 & 88.31 & 64.28 & 78.4 \\
\hline
\end{tabular}

Source: National Bank of Serbia (www.nbs.rs); EU (2013).

Further on observing, insufficient investment is one of the main causes (apart from unfavorable weather conditions - drought and floods) of high Volatility of agricultural production. Instability in production is presented in Table 7 through Agriculture production volume index of goods and services (producer prices, previous year=100) and Food production index.

Table 7. Agriculture and food production index

\begin{tabular}{|l|l|l|l|l|l|l|}
\hline & 2001 & 2008 & 2009 & 2010 & 2011 & 2012 \\
\hline $\begin{array}{l}\text { Agriculture production volume index of } \\
\text { goods and services (producer prices, previous } \\
\text { year=100) }\end{array}$ & 118.0 & 108.0 & 101.0 & 99.4 & 100.9 & 82.3 \\
\hline Food production index & 90.7 & 100.9 & 107.7 & 101.5 & 106.6 & 92.4 \\
\hline
\end{tabular}

Source: FAOSTAT (www.fao.org)

8 The Corruption Perceptions Index ranks countries/territories based on how corrupt a country's public sector is perceived to be. It is a composite index, drawing on corruption-related data from expert and business surveys carried out by a variety of independent and reputable institutions. Scores range from 0 (highly corrupt) to 100 (very clean) for years 2012 and 2013. For other years scores going from 0 to $10.0-10$, where 0 means that a country is perceived as highly corrupt and 10 means that a country is perceived as very clean. 


\section{Discussion and conclusion}

In this paper we have analyzed food security system in Serbia using relevant data from Food and Agriculture Organization (FAO), World Bank (WB), European Commission (EC), and National Statistical Offices, with special emphasis to 2012 indicator Global Food Security Index (GFSI).

The results generally provided two major weaknesses of food security system GDP power purchasing parity per capita and corruption. Observing slow growth of GDP power purchasing parity Serbia is significantly falling behind many neighboring countries, even in comparison to the newest member of EU, Croatia. In the same time corruption remain widespread since the fight against it has not produced significant results. As a consequence Serbia is characterized by fluctuation in the volume of FDI. The largest FDI net inflow is achieved in 2006, after which there is a gradual reduction. Insufficient investment contributes to adverse fluctuations in the level of agricultural production. Analysis of agriculture and food production volume index showed that stability of crop production year by year should be improved.

Difficulties that Serbia is facing lead to the increase of poverty. Poverty in rural areas is twice as high as in urban areas. Similarly, percentage of poor in Central Serbia is more than double higher than in Belgrade. So, we can conclude that poverty in Serbia has become a rural phenomenon and phenomenon of a certain part of country. Child malnutrition as an alternative poverty indicator is worrying issue. Increasing consumption of fast food and total absence of nutritional strategy has contributed to dramatic growth of anemia in children.

Finally, we can conclude that there is a need for food security improvement in Serbia. The greatest responsibility lies on the government which must establish an adequate system. To that aim, first of all, it is necessary to regularly monitor and publish all data indicators. Apart from this, appropriate nutritional standards and strategies will have to be adopted; investors' confidence must be strengthened and must be dealt with in a serious fight against corruption in the agriculture and food sector. The development of rural areas, reducing regional disparities and stabilization of agricultural production will certainly contribute to the tough battle against poverty.

\section{Literature}

1. ActionAid (2010): Who’s Really Fighting Hunger?, Action Aid: Johannesburg, South Africa, September 14 ${ }^{\text {th }}$, (available at: http://www.actionaid.org.uk/sites/default/files/ doc lib/hungerfree scorecard.pdf).

2. AFSI (2009): "L'Aquila" Joint Statement on Global Food Security, (available at: http://www.mofa.go.jp/policy/economy/summit/2009/statement3-2.pdf).

3. Alaimo, K., Olson, C., and Frongillo, E. (2002): Family Food Insufficiency, but not Low Family Income, is Positively Associated with Dysthymia and Suicide Symptoms in Adolescents, Journal of Nutrition no. 132, pp. 719-725.

4. Aziz, T.A. (2001): Sustainable Food Security for all by 2020, IMPRI, September

EP 2015 (62) 3 (801-812) 
4-6, (available at: http://conferences.ifpri.org/2020conference/PDF/summary abdulaziz. pdf).

5. Arezki, R., Brückner, M. (2010): Food Prices and Political Instability, IMF Working Paper, March 2011, (available at: http://www.imf.org/external/pubs/ft/wp/2011/wp1162.pdf).

6. Cook, J., Frank, D. A., Casey, P..H., Rose-Jacobs, R., Black, M.M., Chilton, M., Ettinger de Cuba, S., Appugliese, D., Coleman, S., Heeren, T., Berkowitz, C., Cutts, DB. (2008): A Brief Indicator of Household Food Security: Associations with Food Security, Child Health, and Child Development in U.S. Infants and Toddlers, Pediatrics, vol. 122, no. 4, pp 867-875.

7. $\quad$ Eicher-Miller, H., Mason, A., Weaver, C., McCabe, G., Carol J Boushey, C. (2009): Food Insecurity is Associated with Iron Deficiency Anemia in U.S. Adolescents, American Journal of Clinical Nutrition, no. 90, pp. 1358-1371.

8. $\quad$ EU (2013): Foreign Direct Investments in Serbia, (available at: www.europa.rs/en/ srbija-i-evropska-unijaleu-serbia-trade/fdi-in-serbia.html)

9. FAO (1996): Rome declaration and World food summit plan of action, Rome: FAO, (available at: http://www.fao.org/docrep/003/w3613e/w3613e00.HTM).

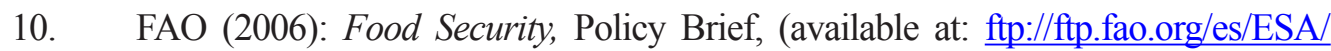
policybriefs/pb 02.pdf).

11. FAO (2011): The State of Food Insecurity in the World, Rome, (available at: http:// www.fao.org/docrep/014/i2330e/i2330e00.htm).

12. FAO (2013): The State of Food Insecurity in the World, (available at: http://www. fao.org/docrep/018/i3458e/i3458e.pdf).

13. GFSI (2012): Global food security index 2012-An assessment of food affordability, availability and quality, A report from the Economist Intelligence Unit, available at:

(http://foodsecurityindex.eiu.com/Country/Details\#Serbia).

14. GFSI (2013): Global food security index 2013-An annual measure of the state of global food security, A report from the Economist Intelligence Unit, (available at: http:// foodsecurityindex.eiu.com/Country/Details\#Serbia).

15. Government of the Republic of Serbia (2012): Monitoring Social Inclusion in Serbia- Overview and Current Status of Social Inclusion in Serbia Based on Monitoring European and National Indicators (2006-2012), Second amended edition, (available at:

http:/www.inkluzija.gov.rs/wp-content/uploads/2013/07/Monitoring-Social-Inclusion-inSerbia-Aug-2012-ENG-revizija.pdf).

16. Hamelin, A. M., Habicht, J. P., Beaudry, M. (1999): Food insecurity: consequences for the household and broader social implications, The Journal of Nutrition, vol. 129, no. 2 , pp, 525-528.

17. Howard,L.(2011):Does Food Insecurity at Home Affect Non-Cognitive Performance at School? A Longitudinal Analysis of Elementary Student Classroom Behavior, Economics of Education Review, no. 30, pp. 157-176.

18. Huang, J., Matta Oshima, K., Kim, Y. (2010): Does Food Insecurity Affect Parental Characteristics and Child Behavior? Testing Mediation Effects, Social Service Review, no. 84, pp. 381-401.

19. IMF (2014): World Economic and Financial Survey, (available at: $\underline{\text { https://www.imf. }}$ 
org/external/pubs/ft/weo/2014/02/weodata/index.aspx).

20. IMF (2012): Global Monitoring Report 2012, IMF and World Bank, Washington DC, available at: (http://siteresources.worldbank.org/INTPROSPECTS/ Resources/334934-1327948020811/8401693-1327957211156/8402494-1334239337250/ Full Report.pdf).

21. Ingram, J. (2011): A food systems approach to researching food security and its interactions with global environmental change, Food Security, vol. 3, no. 4, pp. 417-431.

22. Kirkpatrick, S., Tarasuk, V. (2007): Food Insecurity is Associated with Nutrient Intakes among Canadian Adults and Adolescents, Journal of Nutrition, no. 138, pp. 604-612. 23. Krstić, G. (2008): Poverty profile in Serbia in the period from 2002-2007. In Living Standard Measurement Survey: Serbia 2002 - 2007 (LSMS). Belgrade: Statistical Office of the Republic of Serbia.

24. Papic Brankov, T., Tanjević, N. (2013): Corruption in the land sector, Economics of Agriculture, vol. 60, no. 2, pp. 365-377.

25. Seligman, H., Bindman, A., Vittinghoff, E., Kanaya, A.M., Kushel, M.B. (2007): Food Insecurity is Associated with Diabetes Mellitus: Results from the National Health Examination and Nutritional Examination Survey 1999-2002, Journal of General Internal Medicine, no. 22, pp. 1018-1023.

26. Setboonsarng, S. (2005): Child Malnutrition as a Poverty Indicator: An Evaluation in the Context of Different Development Interventions in Indonesia, ADB Institute Discussion Paper no. 21, (available at: http://www.adbi.org/files/2005.01.14.dp21.malnutrition. poverty.indonesia.pdf).

27. Shepard, D., Setren, E., Cooper, D. (2011): Hunger in America: Suffering We All Pay For, Center for American Progress, Washington DC, (available at: http://www. americanprogress.org/wp-content/uploads/issues/2011/10/pdf/hunger paper.pdf).

28. Skalicky, A., Meyers, A., Adams, W., Yang, Z., Cook, JT., Frank, D.A. (2006): Child Food Insecurity and Iron Deficiency Anemia in Low-Income Infants and Toddlers in the United States, Maternal and Child Health Journal, vol. 10, no. 2, pp. 177-185.

29. UNODC (2011): Corruption in Serbia: bribery as experienced by the population, Vienna, (available at: http://www.unodc.org/unodc/en/frontpage/2011/May/corruption-inthe-western-balkans.html).

30. Večernje novosti online (2013), Trećina generacije anemična, (available at: http:// www.novosti.rs/vesti/zivot +.304.html:450069-Trecina-generacije---anemicna).

31. Whitaker, R., Phillips, S., Orzol, S. (2006): Food Insecurity and the Risks of Depression and Anxiety in Mothers and Behavior Problems in their Preschool-Aged Children. Pediatrics, no. 118, pp. 859-868. 


\title{
PROCENA PREHRAMBENE SIGURNOSTI U REPUBLICI SRBIJI ${ }^{9} 10$
}

\author{
Tatjana Papić Brankov ${ }^{11}$, Miloš Milovanovićc ${ }^{12}$
}

\begin{abstract}
Apstrakt
Opšti cilj ovog rada je analiza sistema sigurnosti hrane u Srbiji preko skupa indikatora sa posebnim osvrtom na globalni indeks sigurnosti hrane (GFSI). Istraživanje je pokazalo da su dve glavne slabosti prehrambenog sistema u Srbiji: bruto domaći proizvod (BDP) po stanovniku zasnovan na paritetu kupovne moći i korpucija. U ovom radu se ukazuje na potrebu unapređenja postojećeg sistema sigurnosti hrane i u tom cilju predlažu se brojne mere. Između ostalog, potrebno je usvojiti odgovarajuće prehrambene strategije i standarde, ojačati poverenje investitora i ozbiljno se pozabaviti borbom protiv korupcije u poljoprivrednom i prehrambenom sektoru. Razvoj ruralnih oblasti, smanjivanje regionalnih dispariteta $i$ stabilizacija poljoprivredne proizvodnje će sigurno doprineti borbi protiv siromaštva.
\end{abstract}

Ključne reči: prehrambena sigurnost, siromaštvo BDP paritet kupovne moći, korupcija.

9 Prva verzija ovog rada prezentovana je na 142. seminaru Evropske asocijacije agrarnih ekonomista, Budimpešta, Mađarska, 29-30 maj, 2014. Zbornik radova nije štampan.

10 Rad je deo projekta III 46006 - “Održiva poljoprivreda i ruralni razvoj u funkciji ostvarivanja strateških ciljeva Republike Srbije u okviru dunavskog regiona (2011-2015)

11 Tatjana Papić Brankov, naučni saradnik, Institut za ekonomiku poljoprivrede, Volgina 15, 11060 Beograd, Srbija, Telefon: +381 6410216 96, E-mail: brankov.tatjana@gmail.com

12 Miloš Milovanović, FAO ekspert, Internacionalnih brigada 69, 11000 Belgrade, Serbia, E-mail: milos.milovanovic@,fao.org 